\title{
METODE MENGAJAR BERVARIASI UNTUK MENINGKATKAN HASIL BELAJAR MATEMATIKA SISWA
}

\author{
Apriyanti ${ }^{1}$, \\ Pendidikan Matematika, FKIP, STKIP-PGRI Bandar Lampung \\ Jl. Khairul Anwar No. 79 Bandar Lampung \\ e-mail:
}

\begin{abstract}
Various problems in the world of education still require concerted thinking efforts; one of these problems is in the field of mathematics studies in schools. This may be due to the way the lesson is delivered that is less effective, for that a teacher can create an interesting learning atmosphere so that it is not boring. A teacher must be able to choose a teaching system that is in accordance with the program of teaching and learning activities. In this study the method used is descriptive quantitative method, data analysis using statistical formulas. To find out student learning outcomes, the writer conducted an essay test. Based on the results obtained, it can be concluded that: "The average mathematics learning outcomes of students who are taught using varied teaching methods are more than the average mathematics learning outcomes of students who are not taught using varied teaching methods". Thus, it can be said that the application of various teaching methods has a positive effect or can improve mathematics learning outcomes.
\end{abstract}

Keywords: Method Teaching Variation, Students Learning Outcomes

\begin{abstract}
Abstrak
Sampai saat ini berbagai masalah dalam dunia pendidikan masih menuntut upaya pemikiran bersama, salah satu masalah ini adalah dalam bidang studi matematika di sekolah. Hal ini mungkin disebabkan oleh cara penyampaian pelajaran yang kurang mengena, untuk itu seorang guru dituntut untuk dapat menciptakan suasana belajar yang menarik agar tidak membosankan. Seorang guru harus mampu memilih sistem pengajaran yang sesuai dengan program kegiatan belajar mengajar. Dalam penelitian ini metode yang digunakan adalah metode deskriptif kuantitatif, analisis data menggunakan rumus statistik. Untuk mengetahui hasil belajar siswa penulis melakukan tes essay. Berdasarkan hasil perhitungan didapatkan, dapat disimpulkan bahwa: "Rata-rata hasil belajar matematika siswa yang diajar dengan menggunakan metode mengajar bervariasi lebih tinggi dari rata-rata hasil belajar matematika siswa yang tidak diajar dengan menggunakan metode mengajar bervariasi". Dengan demikian dapat disimpulkan bahwa penerapan metode mengajar bervariasi berpengaruh positif atau dapat meningkatkan hasil belajar matematika.
\end{abstract}


Kata kunci: Metode Mengajar Bervariasi, Hasil Belajar Matematika

\section{PENDAHULUAN}

Pembelajaran matematika sangat penting untuk meningkatkan penalaran, sedangkan kemampuan penalaran yang tinggi merupakan salah satu indikator dari peningkatan sumber daya manusia yang berkualitas. Kemampuan penalaran dikembangkan melalui pemecahan masalah matematika. Dengan memecahkan masalah matematika dalam pembelajaran, diharapakan kemampuan siswa dalam menguasai materi pelajaran matematika meningkat. Dari beberapa temuan umumnya, siswa mengalami kesulitan dalam menyelesaikan soal-soal matematika, artinya kemampuan pemecahan masalah yang dimiliki oleh siswa relatif rendah.

Sehubungan dengan permasalahan di atas, maka diperlukan upaya-upaya untuk mengatasi kesulitan-kesulitan yang dihadapi oleh siswa. Salah satu upaya yang digunakan untuk mengatasi kesulitankesulitan yang dihadapi siswa adalah dengan menggunakan metode bervariasi. Dengan menggunakan metode bervariasi jalannya pembelajaran tidak membosankan dan dapat menarik perhatian siswa.

Metode belajar yang digunakan dalam suatu pembelajaran hendaknya bervariasi artinya guru sebaiknya tidak hanya menggunakan satu metode, namun menggunakan berbagai metode sekaligus. Hal ini agar murid memiliki kesempatan melakukan kegiatan belajar dan perubahan tingkah laku. (Hamalik, 2003 : 82).

Metode bervariasi di sini adalah gabungan ketiga metode yaitu metode penemuan, pemecahan masalah, dan metode pemberian tugas, dimana pada saat guru memberikan pelajaran kepada siswa timbul suatu masalah dan guru tidak hanya menyelesaikannya dengan hanya menggunakan metode penemuan melainkan membutuhkan metode lain (pemecahan masalah) sebagai jalan keluar dan diakhiri dengan tugas (metode pemberian tugas). Tugas-tugas yang diberikan adalah tugas individu berupa (PR), sehingga siswa dapat melakukan tukar pikiran dalam memecahkan masalah yang dihadapi dan banyak 
menimbulkan kegiatan belajar siswa yang lebih optimal, namun perlu diingat bahwa dalam penggunaan metode tidak selalu menguntungkan kegiatan pembelajaran bila tidak tepat dan sesuai dengan situasi yang mendukung (kondisi siswa dan sarana prasarana yang memadai). Maka dari itu kompetensi guru diperlukan dalam pemilihan metode yang tepat.

Dari uraian di atas penulis menyimpulkan bahwa dalam proses belajar mengajar yang baik adalah mempergunakan metode yang bervariasi yaitu penggunaan beberapa metode mengajar sebagai metode campuran dalam kegiatan belajar mengajar sehingga dapat meningkatkan hasil belajar.

Berdasarkan latar belakang masalah maka dapat diidentifikasikan masalah itu sebagai berikut: (1) Apakah ada pengaruh penerapan metode mengajar bervariasi terhadap hasil pembelajaran matematika; (2) Apakah rata-rata hasil pembelajaran matematika siswa yang diajar dengan menggunakan metode bervariasi lebih tinggi dari siswa yang tidak diajar dengan menggunakan metode bervariasi?

\section{METODE PENELITIAN}

Subjek pada penelitian ini adalah siswa kelas VII semester genap SMP Taruna Jaya Jati Agung Lampung Selatan Tahun Pelajaran 2009/2010. Di dalam penelitian ini, penulis menggunakan metode eksperimen. Metode eksperimen yang akan digunakan penulis dua kelas yaitu satu kelas sebagai kelas eksperimen dan satu kelas sebagai kelas kontrol. Data yang diperoleh dalam penelitian ini berupa skor akhir dari variabel dalam bentuk angka oleh karena itu maka penelitian ini bersifat penelitian kuantitaf. Pada akhir penelitian data tersebut dianalisis dengan menggunakan tabulasi dan rumus statistik untuk menguji hipotesis yang diajukan pada awal penelitian.

Dalam penelitian ini yang menjadi variabel $X$ adalah pengaruh metode mengajar bervariasi dan variabel terikat dalam penelitian ini adalah hasil belajar matematika. 
Dalam proses pengambilan sampel digunakan tehnik random sampling klaster (cluster random sampling) karena populasi yang ada dalam kondisi homogen. Cluster random sampling adalah pengambilan sampel dari beberapa kelas atau kelompok yang ada pada populasi yang benar-benar dianggap mewakili populasi (Arikunto, 2006). Sampel yang akan diambil sebanyak 2 kelas, yaitu satu kelas sebagai kelas eksperimen dan satu kelas sebagai kelas kontrol.

Untuk pengukuran variabel dalam penelitian ini, penulis melakukan tes. jumlah soal yang penulis berikan sebanyak 10 butir soal dalam bentuk essai. Pemberian skor untuk soal sebanyak 10 butir soal dalam bentuk essai tersebut dengan rincian sebagai berikut:

Tabel 1

Pedoman Penskoran Tes Essay

\begin{tabular}{lc}
\hline Kategori & Skor \\
\hline Jika siswa tidak memberikan jawaban & 0 \\
Siswa dapat menulis hal-hal yang diketahui pada soal & 1 \\
Dapat menuliskan hal-hal yang diketahui, ditanyakan, dan menjawab & 2 \\
sesuai dengan jawaban soal tetapi jawaban akhir salah & 3 \\
Dapat menjawab dengan hasil benar & 30 \\
\hline Total Skor Maksimum (10 soal) & \\
\hline
\end{tabular}

\section{HASIL DAN PEMBAHASAN}

Penelitian yang telah dilaksanakan oleh penulis didapat data analisis berupa skor masing-masing siswa dan rata-rata nilai yang diperoleh. Berdasarkan hasil penelitian dari 30 siswa yang terdapat pada kelas eksperimen diperoleh nilai tertinggi yang dicapai siswa adalah 90, sedangkan nilai terendah yang diperoleh siswa adalah 50 . Dari data hasil tersebut dapat diketahui bahwa seluruh responden mempunyai rata-rata nilai adalah 71,6.

Sedangkan dari 30 siswa yang terdapat pada kelas kontrol diperoleh nilai tertinggi yang dicapai siswa adalah 80 , sedangkan nilai terendah yang diperoleh siswa adalah 40. Dari data hasil tersebut 122 


\section{Hipotenusa}

Journal of Research Mathematics Education VOL.3 NO.2 2020

dapat diketahui bahwa seluruh responden mempunyai rata-rata nilai adalah 61,53 .

Tabel 2

Daftar Hasil Perhitungan Tes Siswa yang Menerapkan Metode Mengajar Bervariasi Dan Tanpa Menerapkan Metode Mengajar Bervariasi

\begin{tabular}{cccc}
\hline No & Statistik & Kelas Eksperimen & Kelas Kontrol \\
\hline 1 & Rata-rata & 71,6 & 61,53 \\
2 & Median & 72,1 & 72,1 \\
3 & Modus & 71,7 & 64 \\
4 & Jangkauan & 40 & 40 \\
5 & Varian & 92,37 & 184,67 \\
6 & Simpangan & 9,61 & 13,59 \\
7 & Nilai Tertinggi & 90 & 80 \\
8 & Nilai Terendah & 50 & 40 \\
\hline
\end{tabular}

Tabel 3

Hasil Uji Normalitas

\begin{tabular}{cccc}
\hline Kelas & Hasil Uji & Kriteria Uji & Kesimpulan \\
\hline Kontrol & $\chi_{\text {hit }}^{2}==6,11$ & $\alpha=0,05$ & Ho diterima yang \\
& & diperoleh $\chi_{\text {daf }}^{2}=$ & berarti sampel \\
& & 11,1 & berdistribusi \\
& & terima Ho jika & normal \\
Eksperimen & $\chi_{\text {hit }}^{2}==0,86$ & $\chi_{\text {hit }}^{2}<\chi_{\text {daf }}^{2}$. & Ho diterima yang \\
& & & berarti sampel \\
& & & berdistribusi \\
& & & normal \\
\hline
\end{tabular}

Setelah diperoleh hasil uji kedua data berdistribusi normal, pengujian selanjutnya, yaitu uji homogenitas dengan hasil sebagai berikut

Tabel 4

Hasil Uji Homogenitas

\begin{tabular}{ccc}
\hline Hasil & Kriteria & Kesimpulan \\
Uji & Uji & \\
\hline $\mathrm{F}_{\text {hit }}=$ & $\mathrm{F}_{\text {daf }}=1.85$ & $\mathrm{~F}_{\text {hit }}<\mathrm{F}_{\text {daf }}$ berarti kedua data mempunyai varians yang \\
2,00 & & \\
\hline
\end{tabular}


Dari dua hasil analisis pendahuluan tersebut, dilakukan pengujian hipotesis menggunakan rumus statistik t-tes dan diperoleh nilai $\mathrm{t}_{\text {hit }}=3,57$. dari tabel distribusi $\mathrm{t}$ pada taraf signifikan $5 \%$ diketahui $\mathrm{t}_{\text {tab }}=\mathrm{t}_{(1-1 / 2 \alpha)}=2,00$ dan $\mathrm{t}_{(1-\alpha)}=1,67$ ini berarti $\mathrm{t}_{h i t}>\mathrm{t}_{t a b}$.

Maka dengan ini dapat disimpulkan bahwa ada pengaruh metode mengajar bervariasi dalam meningkatkan hasil belajar matematika pada siswa kelas VII semester genap SMP Taruna Jaya Jati Agung Lampung Selatan tahun pelajaran 2009/2010 dan rata-rata hasil belajar matematika siswa yang diajar dengan menggunakan metode mengajar bervariasi lebih tinggi dari rata-rata hasil belajar matematika siswa yang tidak diajar dengan menggunakan metode mengajar bervariasi. Dengan demikian dapat disimpulkan bahwa penerapan metode mengajar bervariasi berpengaruh positif atau dapat meningkatkan hasil belajar matematika.

Menurut Suherman (1999), metode mengajar adalah langkahlangkah dan cara-cara yang biasanya diterapkan untuk melaksanakan tiap bahan pelajaran dalam suatu kelas. Hal ini berarti metode merupakan hal yang sangat penting yang harus ditetapkan oleh seorang guru untuk keberlangsungan suatu pembelajaran di kelas. Pemilihan metode akan sangat berpengaruh dalam keberhasilan suatu pembelajaran.

Metode mengajar bervariasi adalah cara penyampaian pelajaran yang merupakan beberapa metode dalam penggunaannya untuk menyampaikan materi sesuai dengan pokok bahasan yang menekankan kepada siswa untuk belajar secara aktif dan kreatif.

Metode bervariasi disini merupakan gabungan dari beberapa metode dimana diantaranya adalah sebagai berikut:

1) Metode penemuan yaitu suatu prosedur mengajar yang menitik beratkan studi individual, manipulasi objek-objek, dan eksperimentasi oleh siswa sebelum membuat generalisasi sampai siswa menyadari suatu konsep. 
2) Pemecahan masalah yaitu metode yang mengembangkan kemampuan berpikir siswa untuk memecahkan masalah yang cukup kompleks yang memiliki tingkat tinggi.

3) Metode pemberian tugas yaitu metode penyajian dimana guru memberikan tugas tertentu agar siswa melakukan kegiatan belajar.

\section{KESIMPULAN DAN SARAN}

Berdasarkan hasil analisis dan pembahasan yang telah dijabarkan maka dapat disimpulkan bahwa (1) Ada pengaruh metode mengajar bervariasi dalam meningkatkan hasil belajar matematika pada siswa kelas VII semester genap SMP Taruna Jaya Jati Agung Lampung Selatan tahun pelajaran 2009/2010; (2) Rata-rata hasil belajar matematika siswa yang diajar dengan menggunakan metode mengajar bervariasi lebih tinggi dari rata-rata hasil belajar matematika siswa yang tidak diajar dengan menggunakan metode mengajar bervariasi.

Dari hasil penelitian, maka dapat diajukan beberapa saran yang dapat berguna untuk meningkatkan hasil pembelajaran siswa, yaitu (1) Guru hendaknya dalam pengajaran menggunakan metode yang sesuai dengan materi yang akan diajarkan sehingga dapat meningkatkan hasil belajar siswa; (2) Hendaknya metode bervariasi digunakan dalam memberikan pelajaran matema-tika pada pokok bahasan, sehingga memungkinkan siswa belajar secara aktif dan memperoleh pelajaran langsung. Perlu diciptakan kondisi belajar yang memberi-kan kesempatan kepada siswa secara aktif, hal ini menjadi tugas dan kewajiban guru, sehingga siswa termotivasi untuk belajar matematika lebih lanjut, serta dapat meningkatkan hasil belajar matematika; (3) Siswa hendaknya diingatkan dan dihimbau untuk dapat lebih memanfaatkan waktu yang ada untuk mempelajari kembali materi-materi pelajaran yang telah diberikan sebelumnya. 


\section{Hipotenusa}

Journal of Research Mathematics Education

VOL.3 NO.2 2020

\section{DAFTAR PUSTAKA}

Arikunto, S. 2006. Prosedur Penelitian. Jakarta : Renika Cipta

Hamalik, O. 2003. Metode Belajar \& Kesulitan Belajar. Bandung : Parsito.

Suherman, E. 1999. Strategi Belajar Mengajar Matematika. Jakarata : Universita Terbuka, Dekdikbud. 